\title{
Bivariate Relationship between Passive Energy Parameters and Active Energy Utilization for Comfort in Public Buildings in Southwestern Nigeria
}

\author{
Lawal, A. F, Akinbami, J-F. K, Akinpade J.A and Makinde, F.A. \\ ${ }^{I}$ Department of Project Management Technology, Federal University of Technology, \\ Akure. Ondo State. Nigeria \\ ${ }^{2}$ Department of Building Technology, The Polytechnic, Ibadan. Oyo State. Nigeria \\ ${ }^{2}$ Department of Building Technology, Osun State College of Technology, \\ Esa Oke, Osun State. Nigeria
}

*Corresponding Author: Lawal, Akinloye, Department of Project Management Technology, Federal University of Technology, Akure. Ondo State. Nigeria.

\begin{abstract}
Much of active energy used in the public buildings which are not climate responsive is to make the indoor spaces physiologically comfortable. Field survey and experimental approach were adopted to assess the level of comfort, utilization of building design variables \{climate responsive design (CRD) parameters\} and active energy consumption in selected public buildings in the six States of Southwestern Nigeria.
\end{abstract}

Characteristics of the climate responsive design (CRD) parameters were discussed extensively. The mean satisfaction rating of utilization of passive design parameters was 2.72 on a 5 point Likert rating scale, implying users' low level of satisfaction with the design parameters. The mean active energy consumption to attain the required thermal and visual comfort was $6.89 \mathrm{kWh}$ which is high compared to Givoni's recommendation of $5.50 \mathrm{kWh}$. The analysis of variance test showed that utilization of passive design parameters significantly influenced active energy consumption in the public buildings in all the states of Southwestern Nigeria $(4.3<F<7.7, P<0.05)$.

The contribution of passive design parameters to variance in active energy consumption as measured by squaredsemi partial correlation was significant in all the states $(0.45<S r 2<0.75, p<0.05)$ except in Ondo State $(\mathrm{Sr} 2=0.17)$ and Lagos State $(\mathrm{Sr} 2=0.28)$. The study revealed that correlation existing among pairs of all the variables could explain why the level of active energy consumption varied from state to state and from one subsector to the other.

Keywords: : Active Energy, Passive Energy, Climate Responsive Design (CRD) Parameters, Physiological Comfort, Building Fabrics

\section{INRODUCTION}

Heat radiation from sun penetrates the inner space of the buildings through all fabrics, roofs and openings in walls. When the design (orientation, spatial organization, vegetation, shape and size, the site, ventilation, size and types of windows and material selection) of a building is not energy conscious or climate responsive in such a way that it cannot utilize the passive energy to provide visual and thermal comfort for the inhabitants, it becomes necessary to use active energy to provide the comfort. Active energy in terms of electricity can now be used to run electric fans and airconditioners to meet the required thermal comfort and additional electric light to meet the visual comfort. The attainment of a high level of comfort in buildings (residential and public) depends a great deal on the amount of solar radiation excluded from the interior spaces Ajibola, (2011). Design considerations determining human health, comfort and well being in a building should aim at preventing penetration of direct solar radiation, allow for adequate ventilation and illumination (Su et al, 2016).

When these factors are not adequately considered, much active energy would be used for airconditioning, illumination, etc to attain a high level of comfort (thermal and visual) in buildings. There is however the need for the designers to minimize the use of active energy in public buildings. 
In addition to energy conservation, there are other additional benefits in making use of passive energy in buildings. For instance, some obvious distinctions between natural ventilation and mechanical ventilation system have been observed (Xia and Gang, 2012).

While the driving mode is regarded as the most significant one between them, another distinct difference lies in the power spectrum of wind fluctuation in the low-frequency area, which is recognized as the most important factor impacting the comfort of airflow. The frequency distribution of wind velocity in natural ventilation is skew.

Consequently, in such kind of environment, people are inclined to feel the fluctuation and be comfortable. On the other hand, that of mechanical ventilation system is normal and has an unfavorable effect on thermal comfort. Furthermore, it is well known that the fluctuation of natural wind can make people more comfortable and closer to nature in that it well accords with the so-called 1/f rhythm of body (Shou-lin et al, 2014). Furthermore, the airflow of natural ventilation moves at a low speed for long time which can reduce the feeling of tiredness. The larger turbulence intensity of natural wind is also believed to enhance the feeling of comfort, because it intensifies the heat convection between people and the environment (Shou-lin et al, 2014). Therefore, natural ventilation is better than mechanical ventilation on the whole

\section{Public Buildings Designs}

Public buildings are buildings whose design, construction and operating costs are financed through public fund. Public buildings consist of office, hospital, educational and hotel buildings etc. In most public buildings, there had been heavy dependence on electrical energy for thermal and visual comfort as stated by Wamuo (2013). Most of these buildings are replicas of buildings in the temperate regions. These non-domestic buildings however have been identified as large consumers of energy which varied from one form to the other. A well designed naturally illuminated and ventilated public building with efficient and well controlled services would spend less on energy and maintenance. Tropical buildings which are air-conditioned, deep plan, overgrazed with poor service design and control would spend more funds on energy (Lawal, 2008). In the tropics there is the need to look for alternative building designs which will respond to climate conditions as well as energy conservation so as to be economically suitable. The characteristics of public buildings addressed in this study are discussed below.

\section{FACTORS AfFECTING ENERgy CONSUMPTION}

Factors affecting consumption of energy in buildings are: behavioral characteristics and attitudes of the occupants, equipment installed, architectural design, and building material used. Keeping buildings lighted or cooled are the chief concerns of designers in the tropics. Architectural design, building practices and construction materials can be used to conserve energy according to Dallaire (2014). The orientation of buildings, location and size of windows and other architectural features can reduce heat losses or gains. Use of improved insulating materials and high standards of construction will promote natural air conditioning (Foustel and Dieris, 1992). Use of simple local materials such as brick tiles (instead of asbestos), and high ceiling could lead to energy conservation. Some of these improvements can be achieved by altering building codes and legislating minimal standards. The pricing of different forms of energy can be used to shift consumption from one form to the other. According to John (2002), efficient pricing of energy will affect consumption pattern and resulting in substantial gains in overall economic efficiency and competitiveness and substantial reduction in operating cost. Balogun (2014) also stressed that the pricing of one form of energy usually affects consumption pattern of other forms of energy. Stucker (2014) concluded that an increase in price would be regressive on household energy consumption budget. In a study of household energy use and changes in prices, Dunkerley (1990) indicated a significant response to prices of household energy-price elasticity of between -0-60 and -0.80. Scott (2004) and Hirst et al (2012) have concluded that energy consumption patterns are influenced by income and price of fuel. Consumers paying high fuel prices are likely to purchase improved energy efficient appliances and use them frugally.

\section{DESign STRATEGIES}

Three design strategies with respect to the relationship between energy consumption and thermal and visual comfort in a building are discussed. 


\subsection{Passive Design Strategy}

Passive design strategy seeks to reduce active energy budget of the building by paying close attention to passive energy/climate responsive design (CRD) parameters like building orientation, ventilation illumination, location, size and orientation of windows, vegetation and energy transfer properties of the building materials used (Larsen, 2017). Humphreys (2008) and Hui (2014) stressed that passive design approach makes use of natural energy in the environment which is available to the building through the use of the microclimate, building form and fabric. This design approach demands the interaction of many factors including the best use of the physical site conditions, control of the complete thermal envelope of the building, cost considerations, thermal and visual comforts and the lifestyle of the occupants. He also stressed that many buildings can be operated without external fuel or electricity supplies. Dubin and Chalmers (2016) referred to these buildings as zero-energy or energy-plus buildings which employ the passive design strategies to function adequately and efficiently. Architects can design zero-energy or energy-plus buildings by planning their orientation towards the sun cycles and wind direction.

\subsection{Active Design Strategy}

Active design strategy consists of an energy transfer mechanism and an energy distribution mechanism according to Larsen (2017). The mechanisms employed in active design strategy are manmade plant and equipment; and buildings that make use of these systems are called "conditioned buildings". Though a level of thermal comfort can be guaranteed through active systems, in many cases designers ignore the microclimate as well as the building form and fabric, relying mostly on the plant and equipment. The consequence of this is inefficient building energy use.

\subsection{Combination of Active Design and Passive Design Strategies}

A third design strategy, which is a combination of both active and passive strategies, requires the use of plant and equipment to modify climate in extreme conditions.

\section{STUDY AREA}

Southwestern Nigeria lies within longitude $2^{0} 48^{\prime}-6^{0} \quad 0^{\prime} \mathrm{E}$ and latitude $5^{0} 5^{\prime}-9^{0} \quad 12^{\prime} \mathrm{N}$. South western Nigeria is located in the south western part of Nigeria and shares land borders with the Republic of Benin in the west, Kogi and Edo States in the east, and Kwara State in the north. Its coast in the south lies on the Gulf of Guinea on the Atlantic Ocean. The largest and most influential ethnic group in Southwestern Nigeria is Yoruba In terms of religion Southwestern Nigeria is roughly split half and half between Muslims and Christians with a very small minority who practice traditional religion. Southwestern Nigeria is divided into six states namely Oyo, Ogun, Osun, Ekiti, Ondo and Lagos state. Southwestern Nigeria's largest city is Lagos. Lagos has grown from 300,000 in 1950 to an estimated 15 million today, and the Nigerian government estimates that city will have expanded to 25 million residents by 2025 .

\section{MeTHOdOLOGY}

In this study, the method of field survey and experimental approach were adopted to assess the level of comfort, utilization of building design variables \{climate responsive design (CRD) parameters \} and active energy consumption in selected public buildings in southwestern Nigeria. Questionnaires were administered to operators/users of the public buildings and they were interviewed to record their responses to the thermal environment, level of comfort, utilization of building design variables and active energy consumption in the occupied spaces. The scale of warmth as stated by American Society of Heating, Refrigerating and Air Conditioning Engineers (ASHRAE) (2015) was slightly modified and used in the thermal assessment. This study covered the Southwestern Nigeria public buildings whose major actors were identified as fifty-four respondents from educational sector, fifty-four users of government offices, fourty-eight operators of hospitals, twenty-four respondents from hotels sector, thirty professional Architects/Builders and thirty manufacturers of building materials. Appropriate sampling procedures were adopted in selecting organizations/ institutions out of these six groups of actors of public buildings from whom the primary data for the study were collected. Relevant climatic data for Lagos, Ibadan, Abeokuta, Osogbo, Ado-Ekiti and Akure representing Lagos, Oyo, Ogun, Osun, Ekiti and Ondo States respectively were obtained from the 
Nigerian Meteorological Agency (NIMET) Oshodi Lagos for bioclimatic analysis. The information gathered were edited, coded and the variables given sequential numbers for easy identification using computer programmers. The effective temperature, Mahoney tables and psychrometric charts were prepared using the climate data for examining the results of the survey. Spatial analysis was done for the occupied spaces in the buildings. The type, number and percentage area of openings to floor and walls in each space were used in the ventilation analysis. Bivariate analysis expressed the relationship between two variables, and values of another (Tabachnick and Fideli, 2016). Two types of relationships were established. The Pearson correlation co-efficient was used to achieve the correlation among pairs of variables. Multiple regression analysis (MRA) was used to assess the relationship between active energy consumption as the dependent variable and most effective passive design/climate responsive design (CRD) parameters as independent variables. ANOVA test was also used to test the significance of regression coefficient for active energy consumption and contribution/effectiveness of utilization of most effective independent variables of passive energy/climate response design (CRD) parameters was assessed by squared semi partial correlation $\left(\mathrm{Sr}^{2}\right)$.

\section{TREATMENT OF DATA}

The relationship was between the data on active energy consumption (EC) as dependent variables and level of utilization of (passive energy) climate responsive design (CRD) parameters as independent variables. All these considerations have guided the authors in selecting eleven (11) variables used in the research. These variables are related to thermal, visual and physiological comfort of operators of public buildings and connected with the magnitude of active energy consumption in public building subsectors. These variables were used in bivariate and multivariate analyses. The variables are:

$$
\begin{aligned}
& \mathrm{X} 1 \text { = Natural thermal comfort level } \\
& \mathrm{X} 2 \text { = Natural Visual comfort level } \\
& \mathrm{X} 3 \text { = Location of windows facilitating adequate ventilation } \\
& \mathrm{X} 4 \text { = Fabrics preventing heat gain into the building } \\
& \mathrm{X} 5=\text { Presence of courtyard } \\
& \mathrm{X} 6=\text { Size of windows facilitating } \\
& \mathrm{X} 7=\text { Location of windows facilitating adequate cross ventilation } \\
& \mathrm{X} 8=\text { Spatial organization } \\
& \mathrm{X} 9=\text { Landscape } \\
& \mathrm{X} 10=\text { Orientation of the buildings facilitating natural illumination } \\
& \mathrm{X} 11=\text { Orientation of the buildings facilitating adequate cross ventilation }
\end{aligned}
$$

\section{OBSERVATION, ANALYSIS AND DisCUSSION OF RESUltS}

The mean satisfaction rating of utilization of passive design parameters was 2.72 on a 5 point Likert rating scale, implying users' low level of satisfaction with the design parameters. The mean active energy consumption to attain the required thermal and visual comfort was $6.89 \mathrm{kWh}$ which is high when compared to Givoni's recommendation of $5.50 \mathrm{kWh}$. The analysis of variance test showed that utilization of passive design parameters significantly influenced active energy consumption in the public buildings in all the states of Southwestern Nigeria $(4.3<\mathrm{F}<7.7, \mathrm{P}<0.05)$. The contribution of passive design parameters to variance in active energy consumption as measured by squared semi partial correlation was significant in all the states $\left(0.45<\mathrm{Sr}^{2}<0.75, \mathrm{p}<0.05\right)$ except in Ondo State $\left(\mathrm{Sr}^{2}=0.17\right)$ and Lagos State $\left(\mathrm{Sr}^{2}=0.28\right)$. The contribution of passive design parameters to variation in active energy consumption was significant in all the public buildings examined $\left(0.56<\mathrm{Sr}^{2}<0.69, \mathrm{p}<\right.$ $0.05)$ except Office buildings $\left(\mathrm{Sr}^{2}=0.02\right)$ and Hospital buildings $\left(\mathrm{Sr}^{2}=0.17\right)$. The Pearson correlation coefficient was used to examine the correlation existing among pairs of the variables identified. Multiple regression analysis was used to assess the relationship between active energy consumption as the dependent variable (DV) and the most effective climate responsive design (CRD) parameters as 
Bivariate Relationship between Passive Energy Parameters and Active Energy Utilization for Comfort in Public Buildings in Southwestern Nigeria

independent variables (IVS). The result of the models generated showed that natural visual comfort had significant effect on active energy consumption in Educational Institution buildings $(\mathrm{t}=2.09$, $\mathrm{p}<$ $0.05)$ and Hospital buildings $(t=2.25, \mathrm{p}<0.05)$. Presence of Courtyard had significant effect on active energy consumption in Educational Institution buildings $(\mathrm{t}=2.91, \mathrm{p}<0.05)$ and Hotel buildings $(\mathrm{t}=1.93, \mathrm{p}<0.05)$. It also showed that size of windows had significant effect on active energy consumption in Educational Institution buildings $(\mathrm{t}=1.82, \mathrm{p}<0.05)$ and Hotel buildings $(\mathrm{t}=$ $2.68, \mathrm{p}<0.05)$. The study revealed that the correlation existing among pairs of all the variables that could explain level of active energy consumption varied from state to state and from one subsector to the other.

The summary of satisfaction rating of utilization of passive energy/climate responsive design (CRD) parameters in public buildings in Southwestern Nigeria is presented in Table 1. The later revealed that users of public buildings in Oyo state agreed with 3.37 satisfaction rating with utilization of viable $\left(\mathrm{X}_{1}\right)$ natural thermal comfort level while those in Osun, Ondo, Ekiti, Ogun and Lagos states respectively agreed with $3.16,2.91,3.05,3.53$ and 2.50 satisfaction rating. Public building users in Ogun state agreed with maximum 3.72 satisfaction rating with utilization of variable $\left(\mathrm{X}_{1}\right)$ natural visual comfort level while those in Lagos state agreed with minimum 2.95 utilization rating. Users of public building in Oyo state agreed with 3.00 satisfaction rating with utilization of variable $\left(\mathrm{X}_{3}\right)$ location of windows facilitating adequate ventilation while those in Osun, Ondo, Ekiti, Ogun and Lagos states respectively agreed with $3.12,3.10,2.81,3.10$ and 2.53 satisfaction rating. Public building users in Oyo state agreed with 3.05 satisfaction rating with utilization of variable $\left(\mathrm{X}_{9}\right)$ adequate landscaping while those in Osun, Ondo, Ekiti, Ogun and Lagos states agreed with 2.55, 2.61, $2.33,3.06$ and 2.52 satisfaction rating respectively.

Table1. Distribution of Mean Satisfaction Rating of Utilization of Passive Energy/Climate Responsive Design (CRD) Parameters in Public Buildings Based on States in Southwestern Nigeria

\begin{tabular}{|c|c|c|c|c|c|c|c|}
\hline $\begin{array}{l}\text { Passive Energy/ } \\
\text { Climate } \\
\begin{array}{c}\text { Responsive } \\
\text { Design(CRD) } \\
\text { Parameters }\end{array}\end{array}$ & \multicolumn{7}{|c|}{ SOUTHWESTERN NIGERIA STATES } \\
\cline { 2 - 8 } & OYO & OSUN & ONDO & EKITI & OGUN & LAGOS & MEAN \\
\hline $\mathbf{X}_{\mathbf{1}}$ & $3.37 \mathrm{a}$ & $3.16 \mathrm{a}$ & $2.91 \mathrm{a}$ & $3.05 \mathrm{a}$ & $3.53 \mathrm{a}$ & $2.50 \mathrm{a}$ & $3.07 \mathrm{a}$ \\
\hline $\mathbf{X}_{\mathbf{2}}$ & $3.32 \mathrm{~b}$ & $3.29 \mathrm{a}$ & $3.64 \mathrm{~b}$ & $2.72 \mathrm{~b}$ & $3.72 \mathrm{a}$ & $2.95 \mathrm{a}$ & $3.28 \mathrm{a}$ \\
\hline $\mathbf{X}_{\mathbf{3}}$ & $3.00 \mathrm{a}$ & $3.12 \mathrm{c}$ & $3.10 \mathrm{a}$ & $2.81 \mathrm{~b}$ & $3.10 \mathrm{a}$ & $2.53 \mathrm{a}$ & $2.95 \mathrm{a}$ \\
\hline $\mathbf{X}_{\mathbf{4}}$ & 2.94 & $3.23 \mathrm{c}$ & $2.62 \mathrm{c}$ & 2.85 & $2.82 \mathrm{a}$ & $2.99 \mathrm{a}$ & $2.83 \mathrm{a}$ \\
\hline $\mathbf{X}_{\mathbf{5}}$ & 1.18 & $1.11 \mathrm{c}$ & $1.27 \mathrm{c}$ & $1.14 \mathrm{c}$ & $1.17 \mathrm{c}$ & $1.05 \mathrm{c}$ & $1.15 \mathrm{a}$ \\
\hline $\mathbf{X}_{\mathbf{6}}$ & $3.05 \mathrm{~b}$ & 3.04 & $3.14 \mathrm{c}$ & $2.56 \mathrm{a}$ & $3.09 \mathrm{a}$ & $3.11 \mathrm{~b}$ & $2.99 \mathrm{a}$ \\
\hline $\mathbf{X}_{\mathbf{7}}$ & $3.23 \mathrm{a}$ & $3.04 \mathrm{a}$ & $2.86 \mathrm{a}$ & $2.86 \mathrm{a}$ & $3.00 \mathrm{a}$ & $2.62 \mathrm{a}$ & $2.94 \mathrm{a}$ \\
\hline $\mathbf{X}_{\mathbf{8}}$ & 3.26 & $3.04 \mathrm{a}$ & $3.27 \mathrm{a}$ & $3.14 \mathrm{~b}$ & $3.25 \mathrm{a}$ & $3.00 \mathrm{c}$ & $3.16 \mathrm{a}$ \\
\hline $\mathbf{X}_{\mathbf{9}}$ & $3.05 \mathrm{a}$ & $2.55 \mathrm{a}$ & $2.61 \mathrm{a}$ & $2.33 \mathrm{a}$ & $3.06 \mathrm{a}$ & $2.52 \mathrm{c}$ & $2.69 \mathrm{a}$ \\
\hline $\mathbf{X}_{\mathbf{1 0}}$ & $3.09 \mathrm{~b}$ & $30.4 \mathrm{a}$ & $3.18 \mathrm{~b}$ & $2.57 \mathrm{a}$ & $3.10 \mathrm{a}$ & $2.61 \mathrm{a}$ & $2.92 \mathrm{a}$ \\
\hline $\mathbf{X}_{\mathbf{1 1}}$ & $3.00 \mathrm{a}$ & $2.76 \mathrm{~b}$ & $2.73 \mathrm{a}$ & $2.71 \mathrm{~b}$ & $2.81 \mathrm{a}$ & $2.52 \mathrm{~b}$ & $2.76 \mathrm{a}$ \\
\hline $\mathbf{M E A N}$ & 2.84 & 2.76 & 2.77 & 2.57 & 2.83 & 2.54 & 2.72 \\
\hline
\end{tabular}

Source: Authors Analysis of Field Work (2005)

Means with letter (a) - Significantly correlated at 0.01level, (b) - Significantly correlated at 0.05 level, (c) - High correlation coefficient. The mean are got from respondents rating of Performance:

1=Strongly Dissatisfied, 2= Dissatisfied, 3=Partially Satisfied, 4= Satisfied, 5=Strongly Satisfied

$X_{1}$ : Natural Thermal Comfort Level, $X_{2}$ : Natural Visual Comfort Level, $X_{3}$ : Location of Windows Facilitating Adequate Ventilation, $X_{4}$ : Fabrics Preventing Heat Gain Into The Building, $X_{5}$ : Presence of Courtyard, $X_{6}$ : Size of Windows Facilitating Adequate Ventilation, $X_{7}$ : Location of Windows Facilitating Adequate Cross Ventilation, $X_{8}$ : Spatial Organization, $X_{9}$ : Adequate Landscape, $X_{10}$ : Orientation of the Building facilitating Adequate Natural Illumination, $X_{11}$ : Orientation of the Building Facilitating Adequate Cross Ventilation

Table 2 shows the summary of the Pearson Correlation Coefficient of passive energy/climate responsive design (CRD) parameters and active energy consumption for all the States in Southwestern Nigeria. In Oyo State each of variables $X_{2}, X_{4}, X_{5}$, and $X_{9}$ had correlation coefficient of 0.329, 0.254, 
Bivariate Relationship between Passive Energy Parameters and Active Energy Utilization for Comfort in Public Buildings in Southwestern Nigeria

0.631 and 0.368 respectively with $\mathrm{X}_{5}$ at significant level of 0.01 and $\mathrm{X}_{9}$ at 0.05 level. This revealed that variables $\mathrm{X}_{2}$, and $\mathrm{X}_{4}$ had great influence on active energy consumption (EC). Each of variables $\mathrm{X}_{3}, \mathrm{X}_{7}$, $\mathrm{X}_{9}$, and $\mathrm{X}_{11}$ had correlation coefficient of $0.599,0.611,0.623$ and 0.809 , all at 0.01 significant level with natural thermal comfort and each of variables $\mathrm{X}_{6}$, and $\mathrm{X}_{10}$ had correlation coefficient of 0.527 , and 0.502, all at 0.05 significant level with natural visual comfort. In Osun State each of variables $\mathrm{X}_{2}$, $\mathrm{X}_{4}, \mathrm{X}_{9}$, and $\mathrm{X}_{11}$ had correlation coefficient of $0.335,0.541,0.631$ and 0.349 respectively with $\mathrm{X}_{4}$ at significant level of 0.05 and $X_{9}$ at 0.01 level. This revealed that variables $X_{2}$, and $X_{11}$ had great influence on active energy consumption (EC). Each of variables $\mathrm{X}_{3}, \mathrm{X}_{7}, \mathrm{X}_{9}$, and $\mathrm{X}_{11}$ had correlation coefficient of $0.368,0.643,0.626$ and 0.675 , variables $X_{3}$, and $X_{11}$ at 0.05 significant level while $X_{7}$, and $X_{9}$ at 0.01 significant level with natural thermal comfort and each of variables $X_{8}$, and $X_{11}$ had correlation coefficient of 0.661 , and 0.675 , all at 0.01 significant level with natural visual comfort.

Table2. Summary of the Pearson Correlation Coefficient of Utilization of Passive Energy/Climate Responsive Design (CRD) Parameters and Active Energy Consumption $(k W h)$ in each State.

\begin{tabular}{|c|c|c|c|c|c|c|}
\hline \multirow[t]{2}{*}{ States } & \multicolumn{2}{|c|}{ Active Energy (EC) } & \multicolumn{2}{|c|}{$\begin{array}{l}\text { Natural Thermal } \\
\text { Comfort }\left(\mathbf{X}_{1}\right)\end{array}$} & \multicolumn{2}{|c|}{$\begin{array}{c}\text { Natural Visual } \\
\text { Comfort }\left(\mathbf{X}_{2}\right)\end{array}$} \\
\hline & Designation & $\begin{array}{c}\text { Coefficient } \\
\text { Level }\end{array}$ & Designation & $\begin{array}{c}\text { Coefficient } \\
\text { Level }\end{array}$ & Designation & $\begin{array}{c}\text { Coefficient } \\
\text { Level }\end{array}$ \\
\hline \multirow[t]{4}{*}{ Oyo } & $X_{2}$ & 0.329 & $X_{3}$ & $0.559 * *$ & $X_{6}$ & $0.527 *$ \\
\hline & $\mathrm{X}_{4}$ & 0.254 & $X_{7}$ & $0.616^{* *}$ & $X_{10}$ & $0.502 *$ \\
\hline & $\mathrm{X}_{5}$ & $0.631 * *$ & $\mathrm{X}_{9}$ & $0.623^{* *}$ & & \\
\hline & $\mathrm{X}_{9}$ & $0.368^{*}$ & $\mathrm{X}_{11}$ & $0.809^{* *}$ & & \\
\hline \multirow[t]{4}{*}{ Osun } & $X_{2}$ & 0.335 & $\mathrm{X}_{3}$ & $0.368^{*}$ & $\mathrm{X}_{8}$ & $0.661^{* *}$ \\
\hline & $\mathrm{X}_{4}$ & $0.541 *$ & $\mathrm{X}_{7}$ & $0.643 * *$ & $\mathrm{X}_{11}$ & 0.675 ** \\
\hline & $\mathrm{X}_{9}$ & $0.631 * *$ & $\mathrm{X}_{9}$ & $0.626^{* *}$ & & \\
\hline & $\mathrm{X}_{11}$ & 0.349 & $\mathrm{X}_{11}$ & $0.675^{*}$ & & \\
\hline \multirow[t]{4}{*}{ Ondo } & $X_{1}$ & $0.734 * *$ & $X_{3}$ & $0.546^{* *}$ & $\mathrm{X}_{8}$ & $0.622 *$ \\
\hline & $X_{2}$ & $0.438^{*}$ & $\mathrm{X}_{7}$ & $0.631^{* *}$ & $\mathrm{X}_{10}$ & $0.438^{*}$ \\
\hline & $\mathrm{X}_{4}$ & 0.338 & $\mathrm{X}_{9}$ & $0.745 * *$ & & \\
\hline & $\begin{array}{l}\mathrm{X}_{9} \\
\mathrm{X}_{11}\end{array}$ & $\begin{array}{l}0.438 \\
0.290\end{array}$ & $\mathrm{X}_{11}$ & $0.634^{* *}$ & & \\
\hline
\end{tabular}

Table2 (Continued)

\begin{tabular}{|c|c|c|c|c|c|c|}
\hline \multirow[t]{2}{*}{ States } & \multicolumn{2}{|c|}{ Active Energy (EC) } & \multicolumn{2}{|c|}{$\begin{array}{l}\text { Natural Thermal } \\
\text { Comfort }\left(X_{1}\right)\end{array}$} & \multicolumn{2}{|c|}{$\begin{array}{l}\text { Natural Visual } \\
\text { Comfort }\left(\mathbf{X}_{2}\right)\end{array}$} \\
\hline & Designation & $\begin{array}{l}\text { Coefficient } \\
\text { Level }\end{array}$ & Designation & $\begin{array}{l}\text { Coefficient } \\
\text { Level }\end{array}$ & Designation & $\begin{array}{l}\text { Coefficient } \\
\text { Level }\end{array}$ \\
\hline \multirow[t]{5}{*}{ Ekiti } & $X_{3}$ & $0.450 *$ & $\mathrm{X}_{3}$ & $0.728 *$ & $\mathrm{X}_{5}$ & 0.354 \\
\hline & $\mathrm{X}_{7}$ & 0.252 & $\mathrm{X}_{5}$ & 0.385 & $\mathrm{X}_{6}$ & $0.702 * *$ \\
\hline & $\mathrm{X}_{11}$ & 0.493 & $\mathrm{X}_{7}$ & $0.718 * *$ & $\mathrm{X}_{8}$ & $0.736^{*}$ \\
\hline & & & $\mathrm{X}_{9}$ & $0.589 * *$ & $\mathrm{X}_{10}$ & $0.811^{* *}$ \\
\hline & & & $\mathrm{X}_{11}$ & $0.541 *$ & & \\
\hline \multirow[t]{6}{*}{ Ogun } & $\mathrm{X}_{2}$ & 0.290 & $\mathrm{X}_{3}$ & $0.748 * *$ & $\mathrm{X}_{5}$ & 0.328 \\
\hline & $\mathrm{X}_{6}$ & 0.297 & $\mathrm{X}_{4}$ & $0.710^{* * *}$ & $\mathrm{X}_{6}$ & $0.574 * *$ \\
\hline & $\mathrm{X}_{7}$ & 0.411 & $\mathrm{X}_{7}$ & $0.758 * *$ & $\mathrm{X}_{8}$ & $0.560^{* *}$ \\
\hline & $\mathrm{X}_{11}$ & 0.401 & $\mathrm{X}_{8}$ & $0.541^{*}$ & $\mathrm{X}_{10}$ & $0.700^{* * *}$ \\
\hline & & & $\mathrm{X}_{9}$ & $0.693 * *$ & & \\
\hline & & & $X_{11}$ & 0.589 ** & & \\
\hline \multirow[t]{5}{*}{ Lagos } & $\mathrm{X}_{5}$ & 0.368 & $\mathrm{X}_{3}$ & $0.734 * *$ & $\mathrm{X}_{6}$ & $0.548^{*}$ \\
\hline & $\mathrm{X}_{7}$ & 0.258 & $\mathrm{X}_{4}$ & $0.586 * *$ & $\mathrm{X}_{10}$ & $0.591 * *$ \\
\hline & & & $\mathrm{X}_{5}$ & 0.362 & & \\
\hline & & & $\mathrm{X}_{6}$ & $0.524 *$ & & \\
\hline & & & $\mathrm{X}_{7}$ & 0.773 ** & & \\
\hline
\end{tabular}

Source: Authors Analysis of Fieldwork (2005)

** : Significantly Correlated at 0.01 Level

* : Significantly Correlated at 0.05 Level

$X_{1}$ : Natural Thermal Comfort Level, $\quad X_{2}$ : Natural Visual Comfort Level, $X_{3}$ : Location of Windows Facilitating 
Bivariate Relationship between Passive Energy Parameters and Active Energy Utilization for Comfort in Public Buildings in Southwestern Nigeria

Adequate Ventilation, $\quad X_{4}$ : Fabrics Preventing Heat Gain Into The Building, $X_{5}$ : Presence of Courtyard, $X_{6}$ : Size of Windows Facilitating Adequate Ventilation, $X_{7}$ : Location of Windows Facilitating Adequate Cross Ventilation, $X_{8}$ : Spatial Organization, $X_{9}$ : Adequate Landscape, $X_{10}$ : Orientation of the Building facilitating Adequate Natural Illumination $X_{11}$ : Orientation of the Building Facilitating Adequate Cross Ventilation

Table 3 shows the summary of the Pearson Correlation Coefficient of passive energy/climate responsive design (CRD) parameters and active energy consumption for all the Subsectors in Southwestern Nigeria. In Educational Institution Buildings each of variables $\mathrm{X}_{2}, \mathrm{X}_{3}, \mathrm{X}_{5}, \mathrm{X}_{6}$ and $\mathrm{X}_{9}$ had correlation coefficient of $0.310,0.319,0.398,0.259$ and 0.380 respectively with $\mathrm{X}_{3}$ at significant level of 0.05 level. This revealed that variables $X_{2}, X_{5}, X_{6}$ and $X_{9}$ had great influence on active energy consumption (EC). Each of variables $X_{3}, X_{5} X_{7}, X_{9}$, and $X_{11}$ had correlation coefficient of 0.618, $0.486,0.627,0.387$ and 0.457 , all except $X_{9}$ at 0.01 significant level with natural thermal comfort and each of variables $X_{8}$, and $X_{10}$ had correlation coefficient of 0.622 and 0.339 , at 0.01 and 0.05 significant level respectively with natural visual comfort.

Table3. Summary of the Pearson Correlation Coefficient of Utilization of Passive Energy/Climate Responsive Design (CRD) Parameters and Active Energy Consumption ( $k W h)$ in each Subsector.

\begin{tabular}{|c|c|c|c|c|c|c|}
\hline \multirow[t]{2}{*}{ Subsectors } & \multicolumn{2}{|c|}{ Active Energy (EC) } & \multicolumn{2}{|c|}{$\begin{array}{l}\text { Natural Thermal } \\
\text { Comfort }\left(X_{1}\right)\end{array}$} & \multicolumn{2}{|c|}{$\begin{array}{l}\text { Natural Visual } \\
\text { Comfort }\left(X_{2}\right)\end{array}$} \\
\hline & Designation & $\begin{array}{c}\text { Coefficient } \\
\text { Level }\end{array}$ & Designation & $\begin{array}{c}\text { Coefficient } \\
\text { Level }\end{array}$ & Designation & $\begin{array}{c}\text { Coefficient } \\
\text { Level }\end{array}$ \\
\hline \multirow{5}{*}{$\begin{array}{l}\text { Educational } \\
\text { Institution } \\
\text { Buildings }\end{array}$} & $\mathrm{X}_{2}$ & 0.310 & $\mathrm{X}_{3}$ & $0.618 * *$ & $\mathrm{X}_{8}$ & $0.622 * *$ \\
\hline & $\mathrm{X}_{3}$ & $0.319^{*}$ & $\mathrm{X}_{5}$ & $0.486 * *$ & $\mathrm{X}_{10}$ & $0.339^{*}$ \\
\hline & $\mathrm{X}_{5}$ & 0.398 & $\mathrm{X}_{7}$ & $0.627 * *$ & & \\
\hline & $\mathrm{X}_{6}$ & 0.259 & $\mathrm{X}_{9}$ & $0.387^{*}$ & & \\
\hline & $\mathrm{X}_{9}$ & 0.380 & $\mathrm{X}_{11}$ & $0.457 * *$ & & \\
\hline \multirow{4}{*}{$\begin{array}{l}\text { Office } \\
\text { Buildings }\end{array}$} & $\mathrm{X}_{3}$ & 0.312 & $\mathrm{X}_{3}$ & $0.310 *$ & $\mathrm{X}_{5}$ & $0.334 *$ \\
\hline & $\mathrm{X}_{7}$ & 0.299 & $\mathrm{X}_{7}$ & $0.650 * *$ & $\mathrm{X}_{6}$ & $0.576 * *$ \\
\hline & & & $\mathrm{X}_{9}$ & $0.770 * *$ & $\mathrm{X}_{8}$ & $0.567 * *$ \\
\hline & & & $X_{11}$ & $0.696 * *$ & $\mathrm{X}_{10}$ & $0.772 * *$ \\
\hline \multirow{7}{*}{$\begin{array}{l}\text { Hospital } \\
\text { Buildings }\end{array}$} & $\mathrm{X}_{1}$ & $0.423 *$ & $\mathrm{X}_{3}$ & $0.777 * *$ & $\mathrm{X}_{6}$ & $0.699 * *$ \\
\hline & $\mathrm{X}_{2}$ & 0.289 & $\mathrm{X}_{4}$ & $0.697 * *$ & $\mathrm{X}_{8}$ & $0.413^{*}$ \\
\hline & $\mathrm{X}_{3}$ & $0.381 *$ & $\mathrm{X}_{5}$ & $0.393^{*}$ & $\mathrm{X}_{10}$ & $0.782 * *$ \\
\hline & $\mathrm{X}_{8}$ & $0.380 *$ & $\mathrm{X}_{6}$ & $0.397 *$ & & \\
\hline & $\mathrm{X}_{10}$ & $0.384 *$ & $\mathrm{X}_{7}$ & $0.749 * *$ & & \\
\hline & & & $\mathrm{X}_{9}$ & $0.810 * *$ & & \\
\hline & & & $\mathrm{X}_{11}$ & $0.748 * *$ & & \\
\hline
\end{tabular}

Table 3 (Continued)

\begin{tabular}{|c|c|c|c|c|c|c|}
\hline \multirow[t]{2}{*}{ Subsectors } & \multicolumn{2}{|c|}{ Active Energy (EC) } & \multicolumn{2}{|c|}{$\begin{array}{l}\text { Natural Thermal Comfort } \\
\qquad\left(\mathbf{X}_{1}\right)\end{array}$} & \multicolumn{2}{|c|}{$\begin{array}{l}\text { Natural Visual } \\
\text { Comfort }\left(X_{2}\right)\end{array}$} \\
\hline & Designation & $\begin{array}{l}\text { Coefficient } \\
\text { Level }\end{array}$ & Designation & $\begin{array}{l}\text { Coefficient } \\
\text { Level }\end{array}$ & Designation & $\begin{array}{l}\text { Coefficient } \\
\text { Level }\end{array}$ \\
\hline \multirow{6}{*}{$\begin{array}{c}\text { Hotel } \\
\text { Buildings }\end{array}$} & $\mathrm{X}_{5}$ & 0.392 & $\mathrm{X}_{3}$ & $0.827 * *$ & $\mathrm{X}_{4}$ & $0.605 * *$ \\
\hline & $\mathrm{X}_{6}$ & 0.303 & $\mathrm{X}_{4}$ & $0.557 *$ & $\mathrm{X}_{5}$ & 0.309 \\
\hline & $\mathrm{X}_{10}$ & 0.405 & $\mathrm{X}_{7}$ & $0.855^{* *}$ & $\mathrm{X}_{6}$ & $0.708 * *$ \\
\hline & & & $\mathrm{X}_{8}$ & $0.718 * *$ & $\mathrm{X}_{8}$ & 0.418 \\
\hline & & & $X_{11}$ & $0.746^{* *}$ & $\mathrm{X}_{9}$ & $0.770 * *$ \\
\hline & & & & & $X_{10}$ & $0.688 * *$ \\
\hline \multirow{6}{*}{$\begin{array}{c}\text { All } \\
\text { Buildings }\end{array}$} & $\mathrm{X}_{1}$ & $0.175^{*}$ & $\mathrm{X}_{3}$ & $0.602 * *$ & $\mathrm{X}_{3}$ & $0.179 *$ \\
\hline & & & $\mathrm{X}_{4}$ & $0.359 * *$ & $\mathrm{X}_{5}$ & $0.226 * *$ \\
\hline & & & $\mathrm{X}_{5}$ & $0.349 * *$ & $\mathrm{X}_{6}$ & $0.501 * *$ \\
\hline & & & $\mathrm{X}_{7}$ & $0.690 * *$ & $\mathrm{X}_{8}$ & $0.503 * *$ \\
\hline & & & $\mathrm{X}_{9}$ & $0.625 * *$ & $\mathrm{X}_{10}$ & $0.643 * *$ \\
\hline & & & $\mathrm{X}_{11}$ & $0.627 * *$ & & \\
\hline
\end{tabular}

Source: Authors Analysis of Fieldwork (2005)

** : Significantly Correlated at 0.01 Level

* : Significantly Correlated at 0.05 Level

$X_{1}$ : Natural Thermal Comfort Level, $\quad X_{2}$ : Natural Visual Comfort Level, $X_{3}$ : Location of Windows Facilitating International Journal of Constructive Research in Civil Engineering (IJCRCE) 
Bivariate Relationship between Passive Energy Parameters and Active Energy Utilization for Comfort in Public Buildings in Southwestern Nigeria

Adequate Ventilation, $X_{4}$ : Fabrics Preventing Heat Gain Into The Building, $X_{5}$ : Presence of Courtyard, $X_{6}$ : Size of Windows Facilitating Adequate Ventilation, $X_{7}$ : Location of Windows Facilitating Adequate Cross Ventilation, $X_{8}$ : Spatial Organization, $X_{9}$ : Adequate Landscape, $X_{10}$ : Orientation of the Building facilitating Adequate Natural Illumination, $X_{11}$ : Orientation of the Building Facilitating Adequate Cross Ventilation

The summary of the main statistics of relationship between most effective independent variables of climate responsive design (CRD) parameters and active energy consumption is shown in Table 4.

Table4. Summary of the Main Statistics of Active Energy Consumption ( $k$ Wh) and Most Effective Independent Variables of Climate Responsive Design (CRD) Parameters

\begin{tabular}{|c|c|c|c|c|}
\hline Subsectors/States & $\mathbf{R}^{2}$ & $\mathbf{A R ^ { 2 }}$ & Regression Equations & Sig \\
\hline All Subsectors & 0.179 & 0.167 & $\mathrm{EC}=-1.290+0.651 \mathrm{x}_{1}$ & 0.000 \\
\hline Oyo State & 0.573 & .439 & $\begin{array}{c}\mathrm{EC}=-5.242+1.970 \mathrm{x}_{2}+1.470 \mathrm{x}_{4}- \\
3.176 \mathrm{x}_{5}-0.675 \mathrm{x}_{9}\end{array}$ & 0.011 \\
\hline Osun State & 0.687 & 0.597 & $\begin{array}{c}\mathrm{EC}=-18.896+2.146 \mathrm{x}_{2}+2.540 \mathrm{x}_{4}- \\
2.924 \mathrm{x}_{10}+3.350 \mathrm{x}_{11}\end{array}$ & 0.000 \\
\hline Ondo State & 0.770 & 0.656 & $\begin{array}{c}\mathrm{EC}=-1.370-4.018 \mathrm{x}_{1}+2.252 \mathrm{x}_{2}- \\
2.146 \mathrm{x}_{4}-2.826 \mathrm{x}_{8}+1.978 \mathrm{x}_{9}+3.292 \mathrm{x}_{11}\end{array}$ & 0.001 \\
\hline Ekiti State & 0.459 & 0.364 & $\begin{array}{l}\mathrm{EC}=16.633-2.742 \mathrm{x}_{3} \\
+4.676 \mathrm{x}_{7}-5.750 \mathrm{x}_{11}\end{array}$ & 0.013 \\
\hline Ogun State & 0.576 & 0.470 & $\begin{array}{c}\mathrm{EC}=5.734+2.302 \mathrm{x}_{2}-1.467 \mathrm{x}_{6}+2.748 \mathrm{x}_{7} \\
-3.751 \mathrm{x}_{11}\end{array}$ & 0.009 \\
\hline Lagos State & 0.363 & 0.292 & $\begin{array}{c}\mathrm{EC}=-3.074+14.949 \mathrm{x}_{5} \\
-2.375 \mathrm{x}_{7}\end{array}$ & 0.017 \\
\hline Hotel Buildings & 0.535 & 0.435 & $\begin{aligned} \mathrm{EC}=2.906 & +5.661 \mathrm{x}_{5}-2.284 \mathrm{x}_{6} \\
& +2.628 \mathrm{x}_{10}\end{aligned}$ & 0.011 \\
\hline $\begin{array}{l}\text { Government Office } \\
\text { Buildings }\end{array}$ & 0.099 & 0.033 & $\mathrm{EC}=4.837-0.733 \mathrm{x}_{7}+0.06948 \mathrm{x}_{3}$ & 0.227 \\
\hline $\begin{array}{l}\text { Educational Institution } \\
\text { Buildings }\end{array}$ & 0.366 & 0.270 & $\begin{array}{c}\mathrm{EC}=-11.033+1.499 \mathrm{x}_{2} \\
-2.716 \mathrm{x}_{3}+6.982 \mathrm{x}_{5}+1.477 \mathrm{x}_{6}+2.013 \mathrm{x}_{9}\end{array}$ & 0.008 \\
\hline $\begin{array}{l}\text { Government Hospital } \\
\text { Buildings }\end{array}$ & 0.610 & 0.520 & $\begin{array}{c}\mathrm{EC}=5.070-0.689 \mathrm{x}_{1}+1.581 \mathrm{x}_{2}-0.583 \mathrm{x}_{3} \\
-1.369 \mathrm{x}_{8}-1.155 \mathrm{x}_{10}\end{array}$ & 0.000 \\
\hline
\end{tabular}

Source: Authors Analysis of Field Work (2005)

$X_{1}$ : Natural Thermal Comfort Level, $X_{2}$ : Natural Visual Comfort Level, $X_{3}$ : Location of Windows Facilitating Adequate Ventilation, $X_{4}$ : Fabrics Preventing Heat Gain Into The Building, $X_{5}$ : Presence of Courtyard, $X_{6}$ : Size of Windows Facilitating Adequate Ventilation, $X_{7}$ : Location of Windows Facilitating Adequate Cross Ventilation, $X_{8}$ : Spatial Organization, $X_{9}$ : Adequate Landscape, $X_{10}$ : Orientation of the Building facilitating Adequate Natural Illumination, $X_{11}$ : Orientation of the Building Facilitating Adequate Cross Ventilation

\section{CONCLUSION AND RECOMMENDATION}

Based on the bivariate analysis conducted, it is obvious that various passive design/climate responsive design (CRD) parameters have great influence on active energy consumption for comfort and varies from one state to the other. The observed variation in the passive design/climate responsive design (CRD) parameters showed that influence of active energy consumption for comfort in each state can be explained by the simple fact that climate is dynamic and the building design should also be dynamic. For sustainable economic growth and development, utilization of passive energy/climate responsive design (CRD) parameters which lead to active energy conservation should be encouraged in buildings in the country. However, for serious and beneficial energy conservation in the public buildings sector, the government needs to take some necessary steps. These include [22]:

The government should be seen as the vanguard of utilization of passive energy/climate responsive design (CRD) parameters for active energy conservation. In this regard, steps need to be taken by the various Governments at the federal, states and local governments levels including the armed forces buildings, etc. for aggressive efficient energy use and energy conservation measures in public buildings

National building codes, standards, and regulations should be developed jointly by the various public and private stakeholders such as professional bodies, federal, state and local governments officials, civil organizations, community-based organizations, researchers. The building codes and standards should be based on research of the local climatic conditions; 
Buildings should be rated according to their energy efficiency indices in order to make them attractive for rental and investment;

Energy impact assessment for new buildings should be made compulsory nationwide as is being practised now in Lagos State;

Research and development, demonstration and dissemination in design and materials for energy conscious architecture should be well funded by both government and the private sector;

More awareness campaigns need to be mounted by both government and private sector for continuous education of the populace which consist of would be investors, professionals, planners, law and decision makers on both the macroeconomic and microeconomic benefits of energy conscious buildings; and

There is also the need for energy conscious building parametric and energy efficient devices and measures databank.

\section{REFERENCES}

[1] K.. Ajibola (2011): Design for comfort in Nigeria - a Bioclimatic Approach. Journal of Renewable Energy $23,57-76$.

[2] Z. Zhai and Q. Chen (2015): Performance of Coupled Building Energy and CFD Simulations, Energy and Buildings, 37(4), 333-344.

[3] X. Su, X. Zhang and J. Gao (2016): Evaluation method of natural ventilation system based on thermal comfort in China, Energy and Buildings, 41, 67-70.

[4] M. Xia and Z. Gang (2012): The production of 1/f fluctuate data and thermal comfort, Journal of Beijing University of Aeronautics and Astronautic 28 (3), 253-256.

[5] Z. Shou-lin, L. Wen-bin and D. Jin-bao (2014): Analysis on thermal comfort of natural wind, Journal of Inner Mongolia Agricultural University 25 (1), 11-15.

[6] C. W. Wamuo (2013): Energy management - a tool for enhancing system efficiency, Proceeding of the National Engineering Conference and Annual General Meeting of Nigerian Society of Engineers on Technological Development in Nigeria - Achievement and Challenges in the Third Millennium, The Nigerian Society of Engineers, Lagos, 60-72

[7] A, F. Lawal, Assessment of Public Building Designs for Energy Conservation in Southwestern Nigeria, Unpublished Ph. D. Thesis, Technology Planning and Development Unit, Faculty of Technology, Obafemi Awolowo University, Ile-Ife. Nigeria, 2008.

[8] G Dallaire (2014): Designing Energy Conserving Buildings. Civil Engineering - ASCE (American Society of Civil Engineers). 44 (4), 54-58.

[9] H.E Feustel and J. Dieris (1992): A survey of airflow models for multizone structures, Energy and Buildings, 18,79-100.

[10] T.M. John (2002): Energy Pricing in O.A Seriki,. and A. O Adebulugbe,.(ed.) Conference Proceeding on Energy Issues in Nigeria, Today and Tomorrow. Energy Commission of Nigeria, Lagos, 82-84.

[11] T.A.M Balogun (2014): Energy Utilization in Nigeria in O.A Seriki,. and A. O Adebulugbe,.(ed.) Conference Proceeding on Energy Issues in Nigeria, Today and Tomorrow. Energy Commission of Nigeria, Lagos, 47 - 57.

[12] J.P. Stucker (2014): The impact of energy price increase on households, Santa Monica Co, Rand, First Edition, 26 - 147.

[13] J. Dunkerley (1990): Energy Consumption Patterns and Their Implications for Planning. Conference I Proceedings On ERG: Patterns of Energy Use in Developing Countries. Technical Information Service, Asean Subcommittee on Non-Conventional Energy Research, Thailand, Bangkok, 45 (28), 11 - 48.

[14] R. Scott (2004): Saving money and energy with task lighting. Journal of Building Services and Environmental Engineering. New York, October edition, 1-9.

[15] E. Hirst, R.Geohz, and J. Carvey (2012): Residential energy use: analysis of Diagregate Data. Chattered Institute of Building (CIOB). London, 4 (2), 60 - 70.

[16] K. Larsen (2017): Energy, environment and building, Cambridge University Press, Cambridge, pp. 65-125

[17] M.A. Humphreys (2008): Outdoor temperatures and Comfort Indoors. Bld Res. and Practice (Journal of CIB), 6 (2) 92 - 105.

[18] S.C. M. Hui (2014): Recent developments and analysis in energy efficiency in buildings in Hong Kong, Energy Efficiency in Buildings 1, 6-10.

[19] F.S. Dubin, and G.L. Chalmers. (2016): Energy Conservation Standard, McGraw-Hill, New York. 
[20] ASHRAE (2015): American Society of Heating, Refrigeration and Air Conditioning Engineers, New York.

[21] B.G Tabachnick, and H.S. Fidell, (2016): Using multivariate statistics, (3rd Edition) Harper Collins College Publishers. New York.

[22] J.F.K. Akinbami (2012): Energy conservation in public community and industrial buildings. Paper presented on Energy Conservation and Your Profit in Deregulation Power Regime Conference. Organized by International Energy Services (IES), at Golden Gate Hotel, Ikoyi, Lagos, Nigeria.

\section{AUTHOR'S BIOGRAPHY}

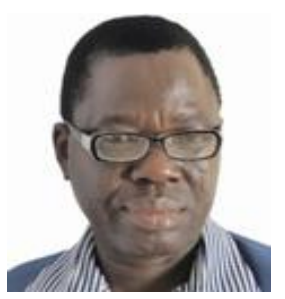

Dr. Akinloye Lawal, holds H.N.D Architecture, B. Sc. Building, M. Sc. (Technology Management) with emphasis in Project Technology Management, Ph. D. (Technology Management) with emphasis in Building Climatology and Energy Management in Buildings. He is a Fellow, Nigerian Institute of Building (FNIOB), Fellow, Institute of Development Finance and Project Management (FIDFPM), Registered Builder, Council of Registered Builders of Nigeria (CORBON) and Corporate Member, Nigeria Institute of Building (MNIOB). He is a Reviewer of many Academic and Professional Journals which includes Nigerian Institute of Building Journals, Nigerian Journal of Environmental Development and Management, Nigerian Journal of Engineering and Environmental Sciences. He is presently an Associate Professor of Construction Project Management in the Department of Project Management Technology, Federal University of Technology. Akure. Ondo State. Nigeria.

Citation: Lawal, Akinloye et al. (2017) Bivariate Relationship between Passive Energy Parameters and Active Energy Utilization for Comfort in Public Buildings in Southwestern Nigeria, International Journal of Constructive Research in Civil Engineering, 3(4), pp.1-10. DOI: http://dx.doi.org/10.20431/24548693.0304001

Copyright: (C) 2017: Lawal, Akinloye. This is an open-access article distributed under the terms of the Creative Commons Attribution License, which permits unrestricted use, distribution, and reproduction in any medium, provided the original author and source are credited. 